\title{
Ice draft and current measurements from the north-western Barents Sea, 1993-96
}

\author{
Einar Povl Abrahamsen, Svein Østerhus \\ \& Tor Gammelsrød
}

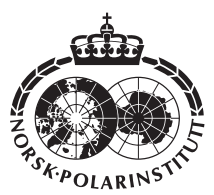

From 1993 to 1996, three oceanographic moorings were deployed in the north-western Barents Sea, each with a current meter and an upwardlooking sonar for measuring ice drafts. These yielded three years of currents and two years of ice draft measurements. An interannual variability of almost $1 \mathrm{~m}$ was measured in the average ice draft. Causes for this variability are explored, particularly its possible connection to changes in atmospheric circulation patterns. We found that the flow of Northern Barents Atlantic-derived Water and the transport of ice from the Central Arctic into the Barents Sea appears to be controlled by winds between Nordaustlandet and Franz Josef Land, which in turn may be influenced by larger-scale variations such as the Arctic Oscillation/North Atlantic Oscillation.

\begin{abstract}
E. P. Abrahamsen, British Antarctic Survey, Natural Environment Research Council, High Cross, Madingley Road, Cambridge CB3 OET, UK, epab@bas.ac.uk; S. Østerhus, Bjerknes Centre for Climate Research, University of Bergen, Allégaten 55, NO-5007 Bergen, Norway; T. Gammelsrød, Geophysical Institute, University of Bergen, Allégaten 70, NO-5007 Bergen, Norway.
\end{abstract}

The Barents Sea plays an important role in the climate system of the Arctic (Schauer et al. 1997; Maslowski et al. 2004, for example). About half of the heat loss to the atmosphere in the entire Nordic seas takes place here (Simonsen \& Haugan 1996), and the water masses in the Barents Sea are therefore strongly modified by cooling, ice formation and brine release (Midttun 1985). When the modified water leaves the Barents Sea in the east, its increased density causes it to enter the Arctic Ocean as an intermediate water mass and influence the deep circulation within the Arctic basins. Gerdes et al. (2003) have demonstrated that the ice extent exerts a strong control on the water mass transformation taking place in the Barents Sea. Sea ice extent data have been available for the Barents Sea over the last few decades from remote sensing (see, for example, Kvingedal $\&$ Sorteberg unpubl. ms.). Very few data, however, are available on sea ice thickness, although indirect measurements have recently begun to emerge from satellite altimetry observations (Laxon et al. 2003).

Here we present two years of ice draft observations obtained from a mooring at $77^{\circ} 55^{\prime} \mathrm{N} 28^{\circ}$ $20^{\prime}$ E equipped with upward looking sonar (ULS). The time series is accompanied by three years of current meter data from the same position. The mooring location is indicated in Fig. 1. To the authors' knowledge this is the only multi-seasonal time series of ice thickness in the Barents Sea. Such datasets are essential for calibrating remotely sensed data, and will serve to help validate numerical models (Budgell 2005, for example).

\section{Instruments and methods}

\section{ULS data}

A ULS was deployed in 1993-94, but unfortunately it did not work; there are no data from this 


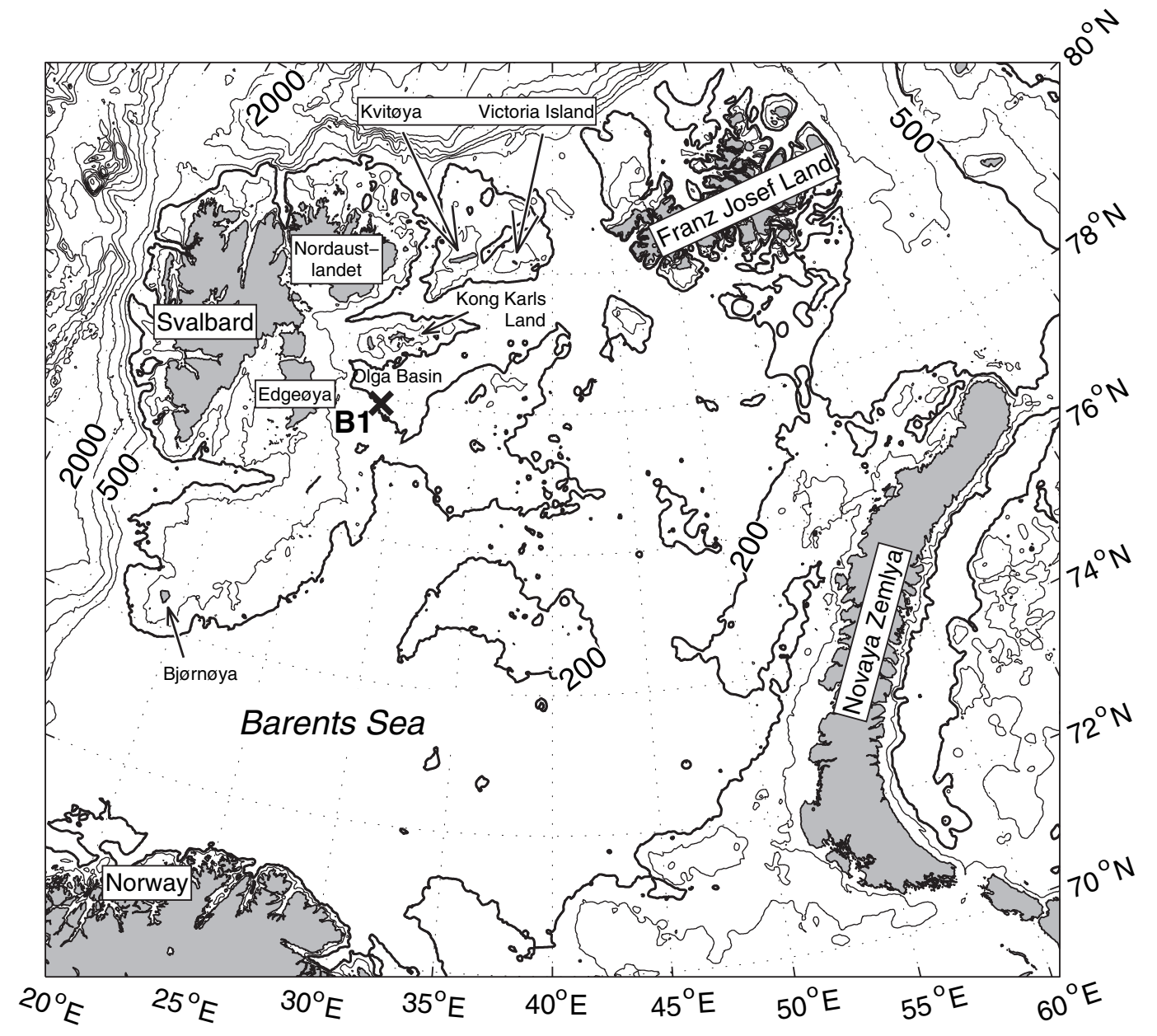

Fig. 1. Map of the Barents Sea. The $200 \mathrm{~m}$ isobath (from IBCAO v. 1) is drawn with a thicker line; other depths indicated are $100 \mathrm{~m}$ and $500 \mathrm{~m}$ and above with $500 \mathrm{~m}$ increments. The bold X marked B1 shows the location of the ULS and current meter mooring.

year. A Christian Michelsen Research (CMR) ES300-IV ULS (Strass 1998) was deployed in 1994, and was replaced in 1995 with an APL (Applied Physics Laboratory, University of Washington) ULS Mark-2 (Drucker et al. 2003). The instruments sampled the ice draft at intervals of 4 and 5 minutes, respectively.

\section{Data processing}

The initial data consist of sonar return times and pressures. The pressures are corrected for varying sea level pressure using quarter-daily sea level pressure data for $77.5^{\circ} \mathrm{N} 27.5^{\circ} \mathrm{E}$ downloaded from the website of the NCAR/NCEP reanal- ysis project at the NOAA-CIRES Climate Diagnostics Center (NCEP 2003). The average density and speed of sound in the water column above the ULS were calculated using temperatures measured in the ULS and in the current meter, along with climatological salinities (from Steele et al. 2001), enabling the pressure and return time to be converted to instrument depth and range, respectively. The target range is then subtracted from the instrument depth to obtain the initial ice draft (or water level) estimate. These estimates were then processed using a method involving satellite-derived ice concentrations to correct the zero level of the data, and to classify the data into open water and ice. This process, more fully described 
by Abrahamsen (2003), is summarized below.

Our source for ice concentration data was the Defense Meteorological Satellite Program (DMSP) Special Sensor Microwave Imager (SSM/I) (Cavalieri et al. 1990). Available for both hemispheres with $25-\mathrm{km}$ resolution, these data have previously been compared with ULSderived measurements (e.g. Harms et al. 2001). We note that in Fig. 8 of Harms et al. (2001), the satellite data appear to yield higher estimates of the ice concentration than the ULS. We experienced the opposite effect, with the satellite data giving slightly lower estimates of the ice concentration. A reason may be that if both ice and water are present in the ULS footprint-in our case this nominally covers a circle approximately $3-7 \mathrm{~m}$ in diameter - the ULS would preferentially measure the ice, especially when the ice concentration is high. We found, empirically, that using the square root as a transfer function for the satellite-derived ice concentrations (thus skewing them towards higher concentrations), yielded better results in the algorithm below, both visually and in terms of the bias in the resulting mean ice drafts (as estimated in the next section). This may not be appropriate in other regions, particularly those that experience lower ice concentrations.

Assuming that a fraction of the ULS measurements that corresponds to the satellite-derived ice concentration is for ice-covered conditions, we know that the remaining points must correspond to open water. Our algorithm uses this to classify each data point as either ice or open water, and to correct the zero level of the data.

We first go through the satellite-derived ice concentration time series for the pixel closest to the mooring and fill in any missing points by linear interpolation. We then take the square root of the ice cover (for reasons described above). We now go through the ULS time series in blocks of 10 days. We found that $7-10$ days works best; with longer blocks, the correspondence between the percentage of open water points and the satellite-derived ice cover will improve, but the longer averaging times will also smear out the profile, ignoring brief events in atmospheric/oceanic conditions. Within each block, if the satellite-derived ice cover is zero, we set the zero level to the median of the draft estimates, subtract it from them, and flag the points as open water. If the mean ice cover is greater than $99 \%$, we set a flag to mark the data as uncorrected, and continue to the next block. If the ice cover $n$ is between 0 and $99 \%$, we sort the data in the block in order of increasing draft. Since the lowest $(100-n)$ percent of our measurements correspond to open water, we set the zero level to the median of the drafts in this range, and flag these points as open water. The use of the median is very robust at determining the zero level, as the mode of the open water distribution should be centred on the mean water level. The rest of the points are flagged as ice, and all points in the block are also marked as uncorrected. We now interpolate the determined zero level to all points previously flagged as uncorrected. The resulting time series is filtered with a 10day low-pass filter and then subtracted from the drafts. We have now determined the zero level for all the data points. The final step is to force the open water points to be distributed evenly around this zero level. Therefore we go through the data blocks with ice concentrations above $0 \%$ again, and, in order of increasing drafts, we successively reclassify data points originally flagged as ice to open water, such that the mean of the (corrected) open water drafts is as close to zero as possible.

\section{Error estimate}

Based on previous validated studies of sea ice drafts using ULS, we estimate that the RMS error of the individual measurements is on the order of $10 \mathrm{~cm}$, while there could be an overall bias towards thicker mean ice drafts of up to $12 \%$ for 1994-95 (Kvambekk \& Vinje 1992; Strass 1998), and probably around 2\% for 1995-96 (Drucker et al. 2003), the difference resulting from the slightly different sampling techniques within the different instruments. This bias is most likely the dominant error in the ice thickness statistics, and, as we have no ice thickness verification data, it cannot be reliably quantified and corrected.

To determine errors resulting from, or remaining after the data processing, we went through the time series and manually indicated the water level for one-week blocks. Compared with this baseline, our data appear to have an overall bias on the order of $3 \mathrm{~cm}$ toward thicker ice, with RMS errors around $6-8 \mathrm{~cm}$.

The open water curves in the histograms in Fig. 2 are approximately Gaussian and centred around zero, as should be expected, at least as a first order approximation, from waves centred around the mean sea level (Podgórski et al. 2000). The "tails" of the histograms for ice drafts $>5 \mathrm{~m}$ are expected to drop off exponentially (Wadhams 2000); this is 
(a)
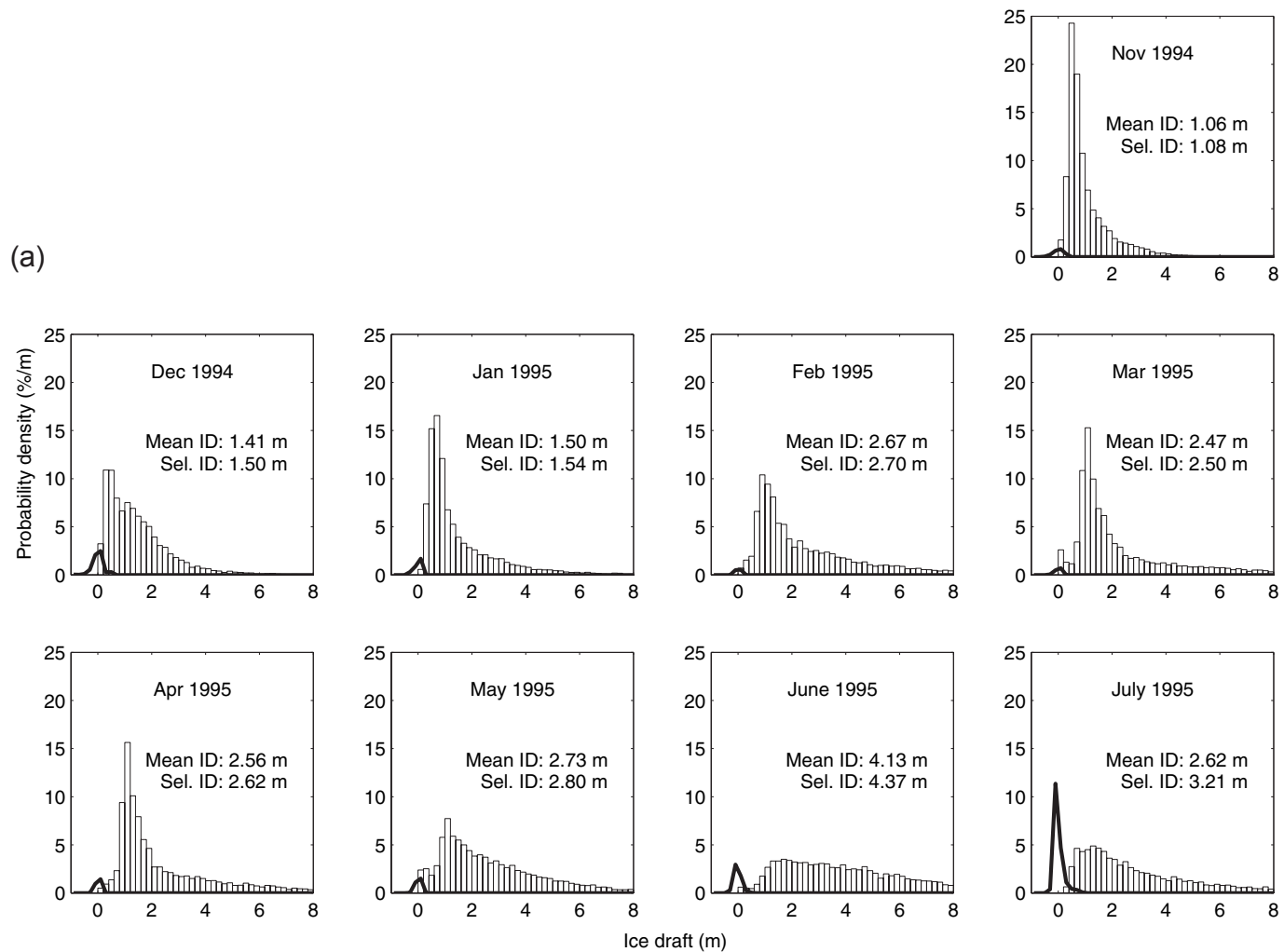

Fig. 2. Histograms of ice drafts from (a) 1994-95 and (b, opposite page) 1995-96. The thick lines are open water, while the histogram is ice. Monthly mean ice draft (including open water) and selective ice draft (excluding open water) are indicated.

the case in most months (not shown).

Melling (1997a, 1997b) found that errors in the ice draft distributions introduced by variations in ice speed could be corrected by weighting the measurements using concurrent ADCP-derived ice velocities (the instruments were mounted side by side on the top of the mooring). We attempted to weight the histograms using daily SSM/Iderived ice velocities (Fowler 2003), but this does not appear to smooth the histograms. On the contrary, it seemed to have the opposite effect. In general, the histograms seem relatively smooth to begin with, indicating that our dataset does not significantly suffer from these errors; consequently our histograms and statistics have not been weighted using ice velocities.

\section{Current meter data}

An Aanderaa Instruments RCM 7 current meter was deployed below the ULS for each year's deployment, and an Aanderaa Instruments WLR 7 pressure recorder was deployed on the bottom for the first year only. Table 1 lists instrument and deployment depths; the latter are also indicated in Fig. 3. The current meters and bottom pressure recorder were set to sample at an interval of one hour. While the temperature measurements of the Aanderaa instruments are reliable, the stability of some of the older conductivity cells is less so. Because of the lack of supplemental data, no attempt has been made to calibrate the salinities,

Table 1. Instruments and deployment depths.

\begin{tabular}{lccc}
\hline & $\begin{array}{c}\text { 13 Aug 1993- } \\
\text { 23 Oct 1994 }\end{array}$ & $\begin{array}{c}\text { 1 Nov 1994- } \\
\text { 22 Jul 1995 }\end{array}$ & $\begin{array}{c}\text { 8 Aug 1995- } \\
\text { 7 Aug 1996 }\end{array}$ \\
\hline ULS & $\begin{array}{c}\text { ES-300-IV } \\
\text { (instr. failure) }\end{array}$ & $\begin{array}{c}\text { ES-300-IV } \\
(133 \mathrm{~m})\end{array}$ & $\begin{array}{c}\text { ULS Mark-2 } \\
(87 \mathrm{~m})\end{array}$ \\
$\begin{array}{l}\text { Current } \\
\text { meter }\end{array}$ & RCM 7 & RCM 7 & RCM 7 \\
$\begin{array}{l}\text { Bottom } \\
\text { pressure } \\
\text { sensor }\end{array}$ & $\begin{array}{c}\text { WLR 8 } \\
(135)\end{array}$ & & \\
\hline
\end{tabular}



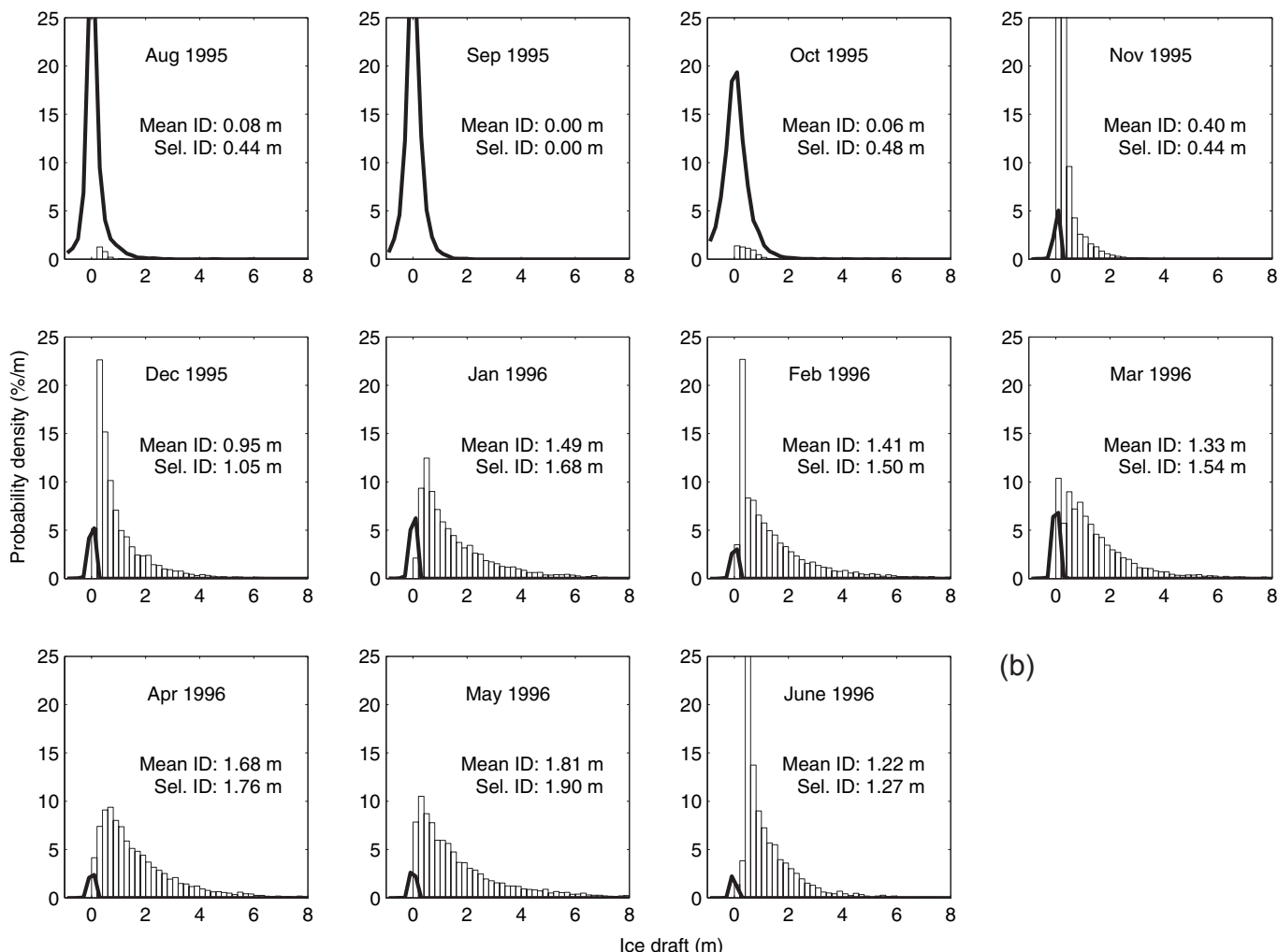

(b)
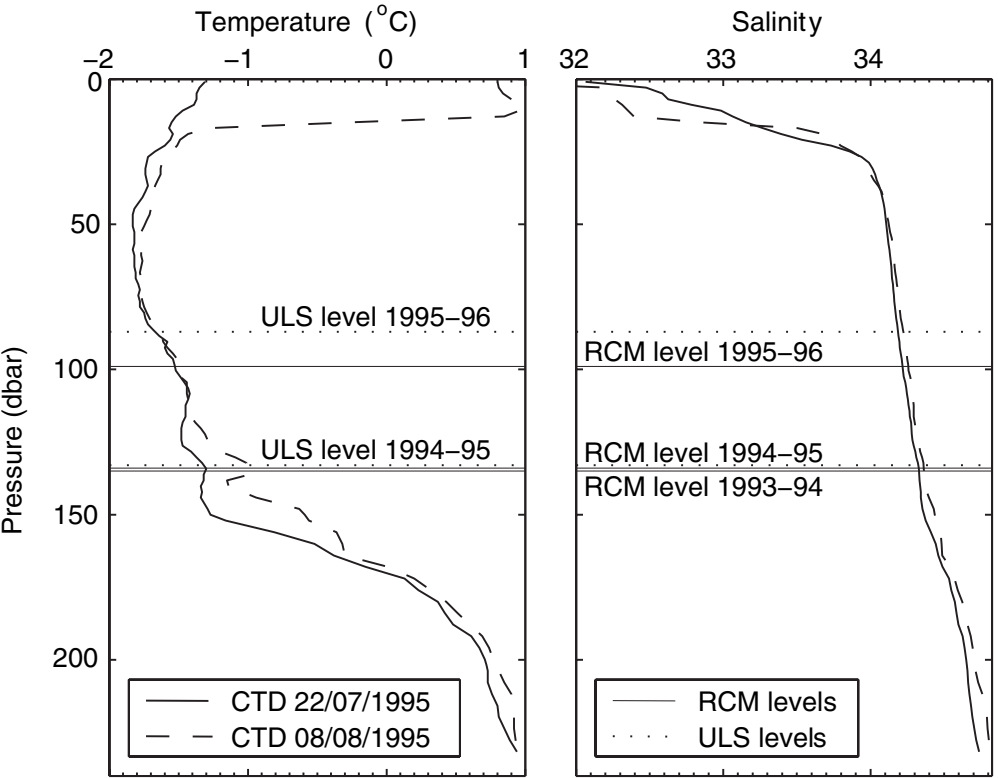

ig. 3. Temperature and salinit profiles from the mooring position, with mooring instrument levels indicated. 
and we consider them to give relative values only. The first year's salinity observations have been discarded because of quality concerns.

\section{Results}

\section{Hydrographic data}

We have two CTD profiles from the Barents and Kara Seas Oceanographic Database (BarKode; Golubev \& Zuyev 1999), taken from RV Lance on 22 July and 8 August 1995, at times corresponding to the recovery and redeployment of the mooring. Both are plotted in Fig. 3.

On 8 August there was a clear thermocline below the surface layer, which is around $20 \mathrm{~m}$ thick; it was not present on 22 July. A slight warming and a clear freshening near the surface occurred after this date. Below this, there seems to be a gradual increase in salinity towards the bottom, where it reaches 34.7. There is a cold core centred at around $50 \mathrm{~m}$, and a warmer water mass at the bottom, extending up to a thermocline at $170 \mathrm{~m}$, where a weaker halocline was also observed. The CTD profiles indicate some variability in the depth of the thermocline. It is clear that the current meter was within this transition zone during the first two years, and further inside the cold water mass during the last year, as is also evident from Fig. 4a.

\section{Currents}

The weekly mean currents from all three years are plotted in Fig. 5. The predominant direction is clearly towards the SSE. The mean speed over all three years was $7.4 \mathrm{~cm} \mathrm{~s}^{-1}$ with an average current of $1.8 \mathrm{~cm} \mathrm{~s}^{-1}$ in the direction of $147^{\circ}$. The current is strongest in October-November in all years. In April 1996 the mean current weakens, leading to a northward mean flow lasting until August.

\section{Tides and bottom pressure}

There is a clear semi-diurnal tidal signal in the current. We can compute the parameters of the various tidal components from a harmonic decomposition of the currents and bottom pressures. The six frequencies with the most energy are given in Table $2 . \mathrm{M}_{2}$, the principal lunar component, clearly dominates, followed by $\mathrm{S}_{2}$, the principal solar component. The $\mathrm{M}_{2}$ "current ellipse" is clockwise, as are $\mathrm{N}_{2}$ and $\mathrm{K}_{2}$; the other ellipses are almost unidirectional. The bottom pressure shows approximately the same relative magnitudes of the tidal components, with spring tide amplitudes on the order of 0.5 dbar. The low-pass filtered pressure series mostly shows variations of around $0.1 \mathrm{dbar}$ amplitude from the mean, with maximum anomalies of 0.24 dbar (not shown).

Table 2. Tidal parameters from the pressure sensors and current meters used for this study; the six strongest components are listed. A negative minor axis indicates clockwise rotation of the current ellipses. Inclinations are given in degrees counter-clockwise from east, while the phases are relative to Greenwich. The current parameters are the average of the three one-year time series from the current meters.

\begin{tabular}{|c|c|c|c|c|c|}
\hline & & Major axis & Minor axis & Inclination & Phase \\
\hline \multirow{6}{*}{ 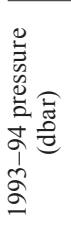 } & $\mathrm{M}_{2}$ & $0.244 \pm 0.002$ & - & - & $126 \pm 1$ \\
\hline & $\mathrm{S}_{2}$ & $0.083 \pm 0.001$ & - & - & $194 \pm 1$ \\
\hline & $\mathrm{K}_{1}$ & $0.082 \pm 0.001$ & - & - & $314 \pm 1$ \\
\hline & $\mathrm{N}_{2}$ & $0.048 \pm 0.002$ & - & - & $92 \pm 2$ \\
\hline & $\mathrm{K}_{2}$ & $0.025 \pm 0.002$ & - & - & $195 \pm 5$ \\
\hline & $\mathrm{P}_{1}$ & $0.025 \pm 0.001$ & - & - & $310 \pm 3$ \\
\hline \multirow{6}{*}{ 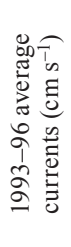 } & $\mathrm{M}_{2}$ & $8.12 \pm 0.25$ & $-1.68 \pm 0.22$ & $73 \pm 2$ & $1 \pm 2$ \\
\hline & $\mathrm{S}_{2}$ & $2.46 \pm 0.25$ & $0.05 \pm 0.21$ & $72 \pm 5$ & $62 \pm 6$ \\
\hline & $\mathrm{K}_{1}$ & $2.07 \pm 0.10$ & $0.03 \pm 0.08$ & $84 \pm 3$ & $138 \pm 3$ \\
\hline & $\mathrm{N}_{2}$ & $1.52 \pm 0.23$ & $-0.26 \pm 0.21$ & $75 \pm 9$ & $329 \pm 9$ \\
\hline & $\mathrm{K}_{2}$ & $0.92 \pm 0.27$ & $-0.20 \pm 0.27$ & $66 \pm 22$ & $53 \pm 23$ \\
\hline & $\mathrm{P}_{1}$ & $0.71 \pm 0.08$ & $0.00 \pm 0.08$ & $87 \pm 6$ & $132 \pm 7$ \\
\hline
\end{tabular}


(a)

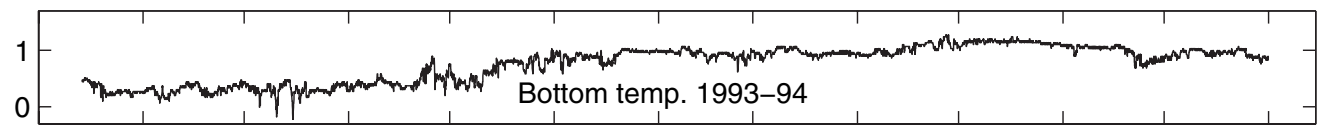

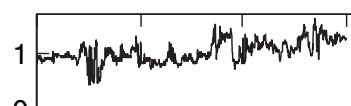

$0-$

Bottom temp. 1994 (cont.)
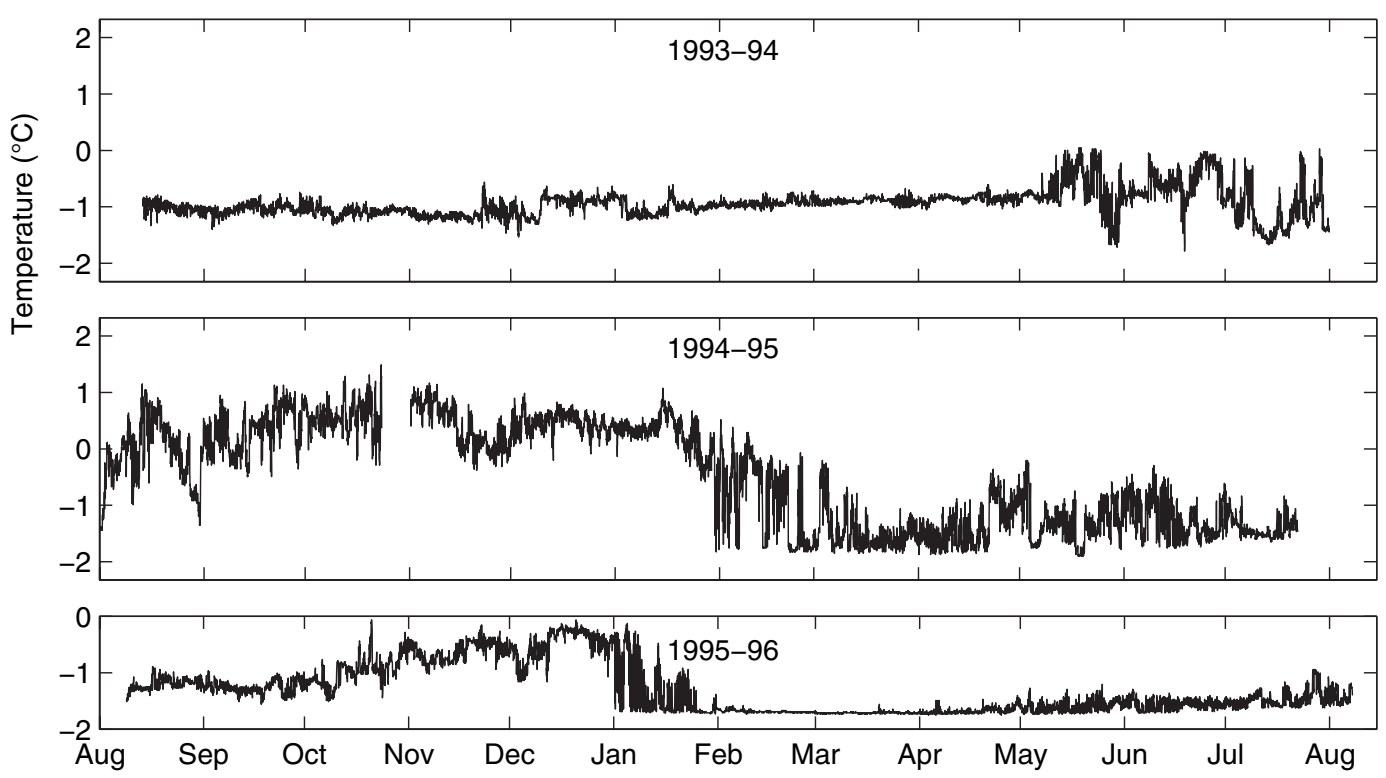

(b)

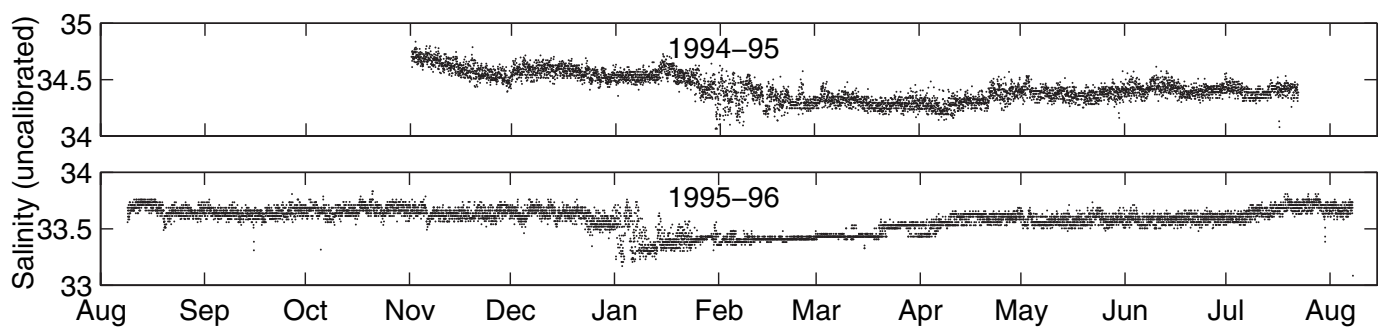

Fig. 4. (a) Temperatures and (b) salinities from the current meters and bottom pressure sensor; see Table 1 for instrument depths. These are unfiltered hourly measurements.

\section{Temperatures and salinities}

The temperature series from the current meters and from the bottom pressure sensor that was deployed for the first year are shown in Fig. 4. The time series from the bottom pressure sensor shows less variation and higher temperatures than the other instruments; all but a few measurements are above $0^{\circ} \mathrm{C}$. Higher in the water column, the RCM temperatures decrease rapidly in late January 1995; there appears to be an oscillation between cold and warm states, where the cold state is close to the freezing point. The temperature rises suddenly in mid-April, and makes several jumps between cold and slightly warmer conditions; the mean temperature rises through the end of the time series. The third year's data have a considerably lower maximum temperature 
1993-94
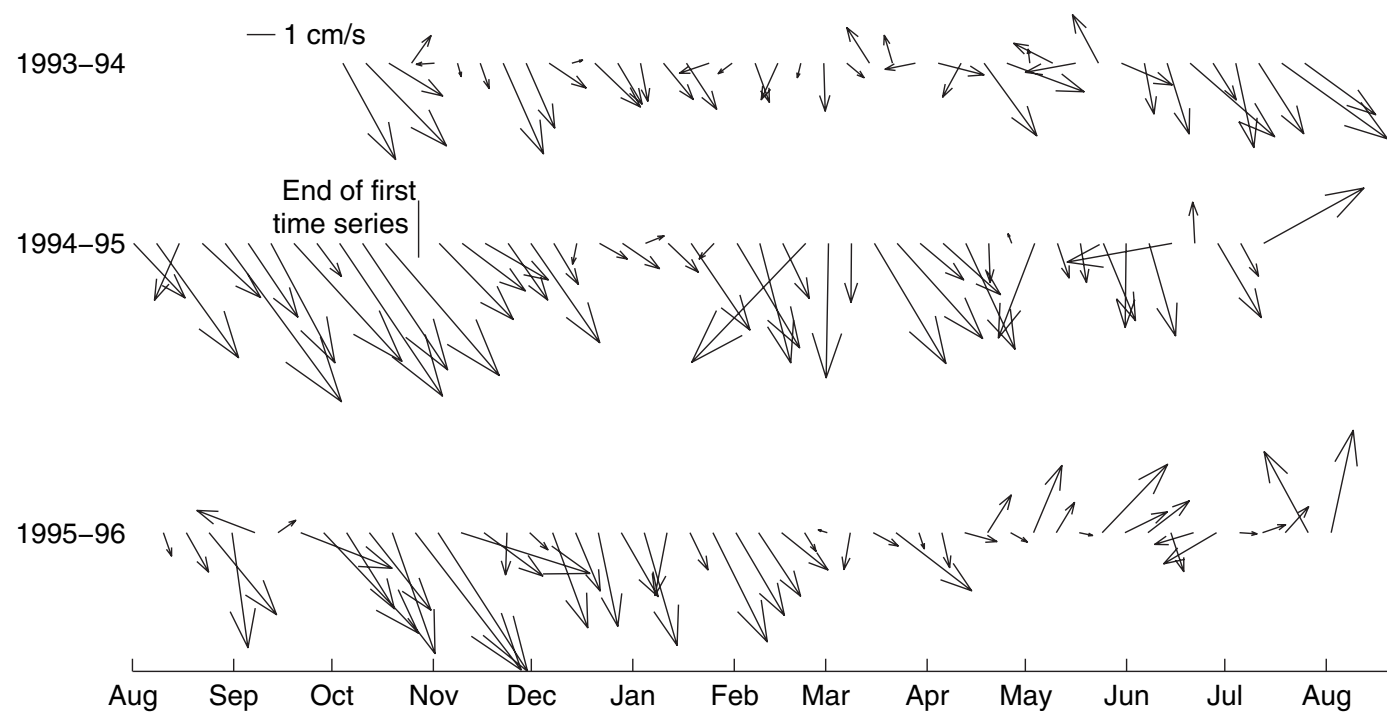

Fig. 5. Weekly mean currents from the three years of measurements. These values are not filtered or detided in any way.

than the two other series. The temperature rises steadily through the fall, but in early January we see a sharp cooling. Once again this appears to be in the form of an oscillation. In February and March the temperature remains close to freezing, while the salinity rises slightly, with much less variation than is otherwise seen. There appears to be a fairly strong correspondence between the variations in temperature and salinity.

\section{Ice draft}

As a result of the long sampling intervals (4-5 min), the measured ice drafts must be considered as a statistical sample of the ice drafts present at the mooring location, rather than a profile of the ice topography; individual features on the bottom of the ice are not resolved. Almost all analyses of these data are based on daily or monthly means and distributions of drafts. Thus, we must clarify some of the definitions used in this paper. When referring to the mean ice draft, we mean the mean draft including open water. In some of the literature this is also called the "effective ice draft." When we refer to means of only the measurements flagged as ice, they are called "selective ice drafts." For the sake of completeness they are indicated in Figs. 2 and 6. Because of the relatively small fraction of open water measurements outside the summer months, the difference between these values is much smaller than is the case in, for instance, Fram Strait (Kvambekk \& Vinje 1992).

The time series of daily mean ice drafts (Fig. 6), shows a very clear difference in draft between our two years of data. 1994-95 had much thicker ice than 1995-96-the February-May mean drafts were $2.61 \mathrm{~m}$ and $1.56 \mathrm{~m}$, respectively. Another prominent feature is the occurrence of several brief minima in the spring of 1996. Figure 2 shows the monthly distribution of ice drafts, with a curve for open water superimposed. The mean and selective mean ice drafts are also indicated.

\section{Discussion}

\section{Currents and hydrography}

According to the water mass definitions of Pfirman et al. (1994), the cold core seen at around $30-80 \mathrm{~m}$ depth in Fig. 3 is Arctic Water (AW), a cold water mass formed locally by cooling and subsequent convection. The warmer, more saline water below is probably Northern Barents Atlantic-Derived Water (NBAW), a branch of the West Spitsbergen Current that has followed the continental shelf around Svalbard before entering the Barents Sea from the north. This is consistent with Pfirman et al.'s (1994) description of a warm core of NBAW flowing south-west through 


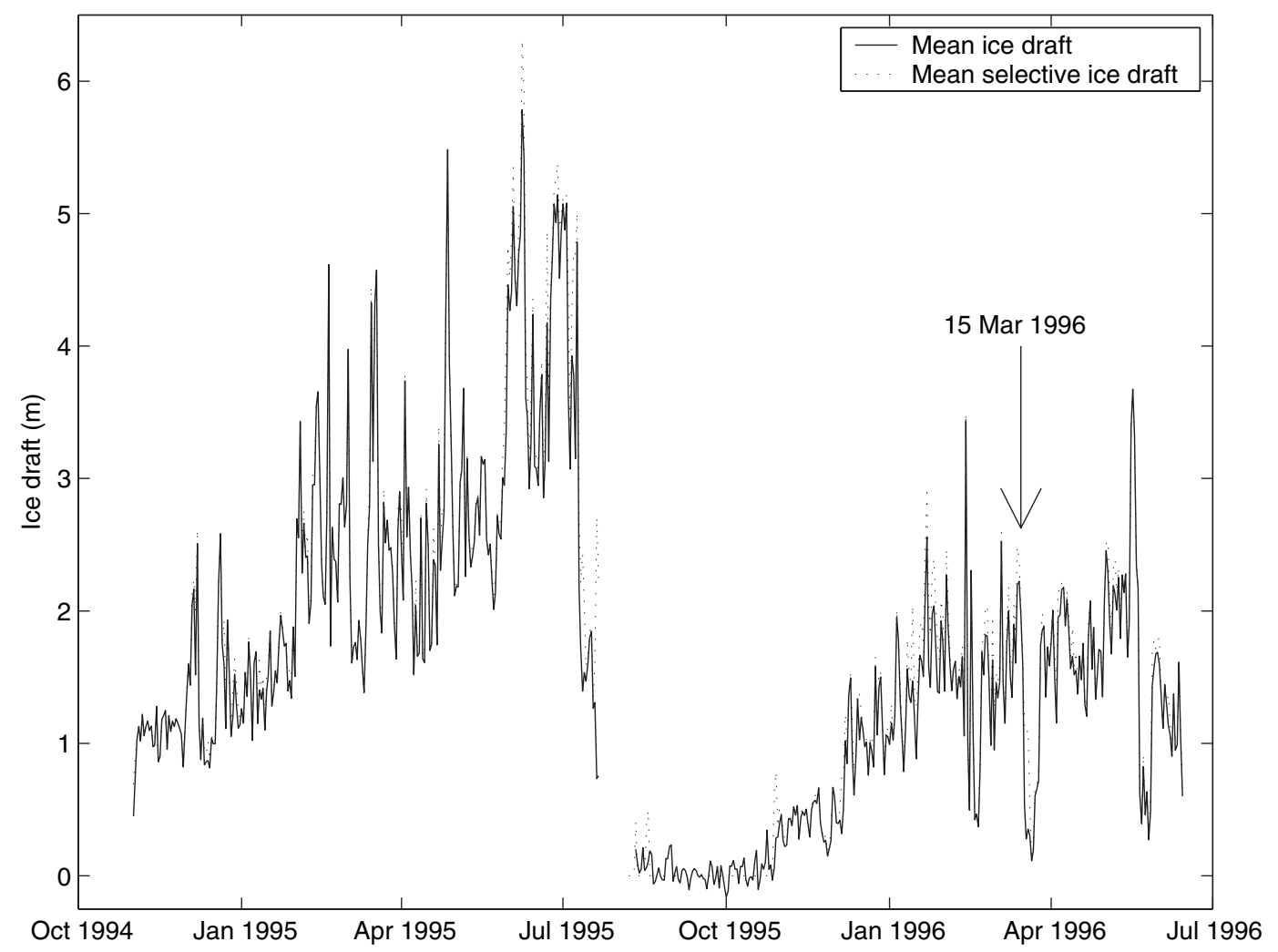

Fig. 6. Time series of daily mean ice drafts. Both the mean draft (with open water) and the selective mean draft (excluding open water) are shown.

the straits between Kvitøya and Franz Josef Land into the Barents Sea, with a temperature maximum around $200 \mathrm{~m}$. The current meter is in the boundary between the AW and NBAW layers for the first two years, and is further inside the AW layer during the third year. Both water masses would be expected to flow in the same direction: towards the south-west; they are topographically steered along the isobaths around the Olga Basin towards the SSE, with a predominant current direction of about $150^{\circ}$ (Fig. 1).

The steady rise in salinity at near freezing temperatures between January and May 1996 is a result of brine rejection from freezing. The oscillations in temperature seen in February-March 1995 and January 1996 are probably caused by a front between NBAW and AW passing by the mooring location. Such a front (the Polar Front) is known to exist between AW and Southern Barents Atlantic-Derived Water (SBAW), which has entered the Barents Sea between Norway and Bjørnøya (Bear Island) further south (Loeng
1991).

The presence of a front is also indicated by a (relatively weak) correlation between the temperature and the two-day mean of the southward component of the current, particularly in the third year, when the current meter was higher in the water column. When the NBAW current is stronger, the interface between NBAW and AW is raised, giving higher temperature measurements and vice versa.

\section{Interannual variation in ice draft}

There are two possible explanations for the rather large ice drafts in 1994-95 compared with 199596: either the ice is deformed locally, or it is multiyear ice advected from the Arctic Ocean. It is impossible to achieve the observed differences in thickness merely through differences in the rate of thermodynamic freezing. A calculation based on cumulative freezing degree days from the IABP/ POLES surface air temperature fields (Rigor et 
al. 2000), gave a thickness of $126 \mathrm{~cm}$ by the end of March 1995 versus $122.5 \mathrm{~cm}$ in 1996, using the (empirical) thermodynamic growth equation of Lebedev (cited in Wadhams 2000):

$$
H=1.33 \theta^{0.58}
$$

where $\theta$ denotes the cumulative freezing degreedays and $H$ is the ice thickness in $\mathrm{cm}$. Although the actual interannual temperature variations may have been larger than indicated by the POLES dataset, they cannot fully explain a difference in ice thickness of more than $1 \mathrm{~m}$. Deformation - ridging and rafting of ice-is probably also important in this area, since there is relatively little open water and tidal currents are up to $10 \mathrm{~cm} \mathrm{~s}^{-1}$ amplitude.

Periods with increased concentrations of multiyear ice also occur. SSM/I-derived multiyear ice fractions (not shown) indicate that a significant part of the ice could be multiyear, especially in late May-June 1995, and, more surprisingly, in January-April 1996. Although the uncertainties of the multiyear fractions are high, the histogram in June 1995 (see Fig. 2a) shows a large fraction of thick ice compared with the preceding months, consistent with an increased fraction of multiyear ice.

\section{Relationship to atmospheric circulation}

Past decreases in ice extent in the Arctic Ocean have been linked to atmospheric circulation changes, for example by Maslanik et al. (1996). They go further to hypothesize that these circulation anomalies may be linked to other atmospheric anomalies such as the El Niño-Southern Oscillation (ENSO) and North Atlantic Oscillation (NAO) patterns in the early 1990s.

In the Barents Sea, Kvingedal \& Sorteberg (unpubl. ms.) found that the sea ice extent seems to be related to the cyclone activity in east Sibe- ria and south of the Barents Sea. They found high cyclonic activity in east Siberia to be related to cold winds from the north, stimulating ice growth and transport of ice from the Arctic into the Barents Sea. High cyclonic activity south of the Barents Sea also gives a larger sea ice extent, because the wind distribution seems to slow the inflowing SBAW.

Further east, in the Kara and Laptev seas, Haas \& Eicken (2001) performed late summer measurements of sea ice thickness in 1995 and 1996 using drilling and a towed electromagnetic induction profiler. They found large interannual variability in ice thickness in the Laptev Sea, of the same order as our measurements, but unlike us, they observed greater ice thickness and concentration in 1996 than 1995. They explained this by noting that the mean sea-level pressure charts for July and August show a low pressure over the Barents Sea and a high pressure over the Canadian Basin in 1995, contrasted with the presence of a very deep low pressure centred on the North Pole in 1996. While the pressure distribution in 1995 would cause ice to flow from the Laptev Sea into the central Arctic, the opposite would occur in the Barents Sea, where ice would be forced from the Kara Sea and central Arctic southward towards our mooring location. On the contrary, in 1996 we would expect to see a net northward (or north-eastward) flow of ice from the northwestern Barents Sea.

Vinje (1985) used meteorological charts to estimate the wind speed between Nordaustlandet and Franz Josef Land, and estimated monthly ice fluxes by assuming that the ice moved at $1 \%$ of the wind speed and had an average concentration of 0.7 and an average thickness of $2 \mathrm{~m}$. From this, he calculated monthly and net annual ice volume fluxes from the Barents Sea to the Arctic Ocean, from 1968-1977. We have done the same using the $10 \mathrm{~m}$ wind fields from the NCEP reanalysis

Table 3. Estimated net ice volume transports (in $\mathrm{km}^{3}$ ) between Nordaustlandet and Franz Josef Land for 1994-96 (individual months and average over all three years) and averages for 1968-1977 (from Vinje 1985). Positive values are northward transport, from the Barents Sea into the Arctic Ocean. For details on how these values were calculated, see the text.

\begin{tabular}{lcccccccccccccc}
\hline Year & Jan & Feb & Mar & Apr & May & Jun & Jul & Aug & Sep & Oct & Nov & Dec & Jan-Dec & Sep-Aug \\
\hline $1968-1977$ & -17 & -26 & -8 & 4 & 12 & 13 & -4 & 4 & 1 & 3 & -13 & -4 & & -35 \\
1994 & -15 & -4 & 23 & 8 & -10 & 24 & 26 & -2 & 4 & -43 & -21 & 1 & -7.5 & -166.2 \\
1995 & -35 & -17 & -8 & -10 & -8 & 2 & -11 & -21 & -2 & -32 & -37 & -32 & -211.4 & -97.1 \\
1996 & -1 & -13 & 3 & -4 & -21 & 21 & 11 & 12 & 51 & -17 & -6 & -14 & 20.2 & \\
$1994-96$ & -17 & -11 & 6 & -2 & -13 & 16 & 9 & -4 & 18 & -31 & -21 & -15 & -66.2 & \\
\hline
\end{tabular}


for 1994-96. The results are shown in Table 3. Given the large interannual variations in ice draft observed here, Vinje's assumption of a constant $2 \mathrm{~m}$ ice thickness is not valid in our case. This type of calculation therefore provides only order of magnitude estimates of the ice flux. During the months when sea ice was present, these values are highly correlated with the Polar Pathfinder satellite-derived ice velocities (Fowler 2003) integrated across the area between Nordaustlandet and Franz Josef Land, although the ice velocity appears to be on the order of $0.4 \%$ of the wind speed, rather than Vinje's $1 \%$.

We found a strong correlation (0.62) between the monthly average north/south component of our current measurements and these ice fluxes, with a one-month lag applied to the currents. This would indicate that the flux of ice as well as of NBAW is largely controlled by the wind across this passage. In turn, these winds are controlled by the large-scale atmospheric circulation in the Arctic, particularly the Northern Annular Mode (Thompson \& Wallace 2000; Krahmann \& Visbeck 2003).

As shown in Table 3, Vinje (1985) found that ice is normally imported from the Arctic Ocean in November-March, and exported into the Arctic Ocean in April-June; this is based on an average of ten years of data. We note that in October-November 1994 and January 1995 ice import is large. Apart from June 1995, when there is a very small export, the rest of 1995 has ice fluxes into the Barents Sea. In 1994 and 1996 we see exports in March and June-September. This leads to much lower flux estimates for 1994 and 1996 compared with 1995. The seasonal fluxes from September-August show that more ice is imported from the Arctic Ocean in 1994-95 than in 1995-96, although the difference here is smaller. Most of our magnitudes measured are larger than Vinje's, probably because of his longer averaging period.

The Arctic Oscillation (AO) index (Thompson \& Wallace 2000) was positive for most of 1994 , decreasing sharply in February 1995, and fluctuating around a slightly negative value for the remainder of our study period. This would give south-easterly winds in the Barents Sea in 1994, causing increased ice convergence and deformation during the freezing season, while the opposite was the case in 1995-96. This may also have contributed to the large difference in ice thickness.

\section{Reduction of ice thickness in March 1996}

Short-scale episodes and features in the data can be interpreted using SSM/I-derived ice concentrations (Cavalieri et al. 1990), together with SLP fields from the NCEP/NCAR reanalysis (NCEP 2003). An example is the episode with reduced ice drafts in mid-March 1996. Satellite-derived ice concentrations are plotted in Fig. 7 and provide the following explanation for the reduction in draft in mid-March. As a result of strong south-westerly winds around 10-12 March, the ice started to open up east of Edgeøya and Nordaustlandet. This polynya extended out towards the mooring location, leading to much lower ice thicknesses. Soon after the wind calmed, the opening started to close up, until it was completely closed by 20 March. The subsequent variation in ice thickness is evident in Fig. 6.

\section{Conclusions}

We have investigated a unique record of ice thicknesses in the north-western Barents Sea from 1994-96, and current and temperature measurements from 1993-96 in the same location. We have observed higher water temperatures when the southward component of the currents was strongest, and hypothesize that this represents a stronger influx of NBAW, displacing the boundary between NBAW and AW upwards. At the same time, there is a clear correspondence between the meridional wind and ice transport between Nordaustlandet and Franz Josef Land, which in turn correlates well with the currents, which they lead by approximately one month. We therefore believe that the wind between Nordaustlandet and Franz Josef Land plays a key role in driving the exchange of both ice and water between the Arctic Ocean and the Barents Sea.

This is supported by the presence of NBAW in the temperature series in the latter half of April and in late June-early July 1995, concurrent with what appears to be multiyear ice, presumably from the Arctic Ocean, in the ULS series. In the third year, we see much weaker signals. While it would be a mistake to compare the temperature time series directly because of the difference in instrument depths, it seems likely that the NBAW flux this year is lower, probably also contributing to the lower ice drafts but larger ice extent observed that year. The reversal in currents 


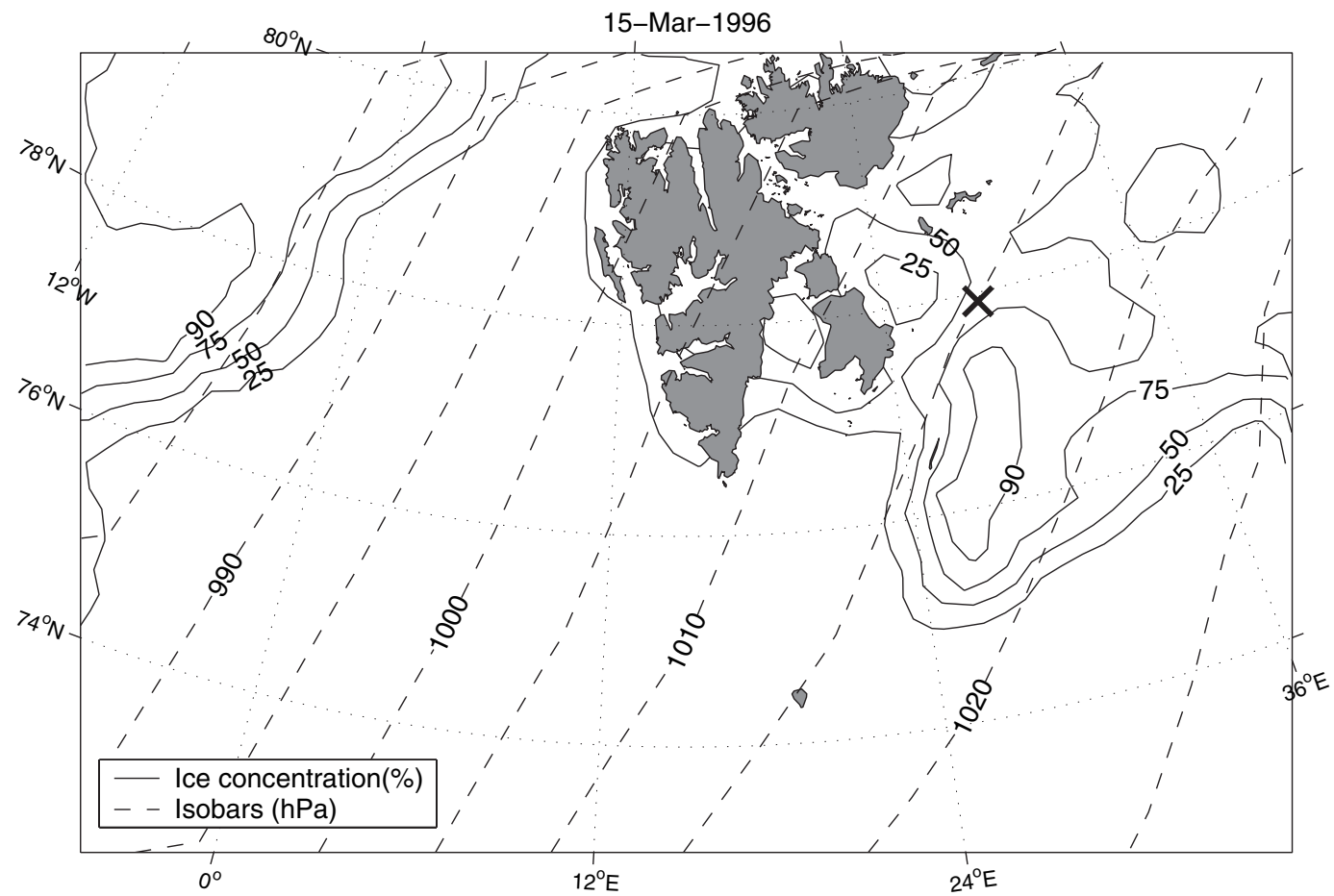

Fig. 7. Satellite-derived ice concentration for 15 March 1996. Isobars of SLP on 12 March 1996 from the NCEP reanalysis are shown; spacing is $5 \mathrm{hPa}$. The mooring location is marked with an $\mathrm{X}$.

this year supports the conclusion that the NBAW flux is weakened, also leading to lower (or even reversed) AW transports.

We have observed that interannual variations in mean ice draft can be extremely large, on the order of $1 \mathrm{~m}$, in the north-western Barents Sea, and are probably driven partly by Atlantic influx and partly by wind circulation, both of which may be correlated to the NAO/AO (Schauer et al. 1997; Furevik 2001), but with different time lags.

Acknowledgements.-E. P. Abrahamsen was at the Geophysical Institute, University of Bergen, at the time this research was carried out. Thanks to Torgny Vinje for initiating these measurements, to the Norwegian Polar Institute for providing the ULS data, and to Harald Loeng for helpful comments on the original thesis on which this paper is based. Thanks also to the two anonymous reviewers and Keith Nicholls, whose comments have greatly improved this paper.

\section{References}

Abrahamsen, E. P. 2003: Ice thickness in the Barents Sea: measurements and modeling. Master's thesis, University of Bergen.

Budgell, W. P. 2005: Numerical simulation of ice-ocean variability in the Barents Sea region: towards dynamical downscaling. Ocean Dyn. 55, 370-387, doi:10.1007/s10236-0050008-3.

Cavalieri, D., Gloerson, P. \& Zwally, J. 1990 (updated 2005): DMSP SSM/I daily polar gridded sea ice concentrations. J. Maslanik \& J. Stroeve (eds.). Boulder, CO: National Snow and Ice Data Center. Digital media.

Drucker, R., Martin, S. \& Moritz, R. 2003: Observations of ice thickness and frazil ice in the St. Lawrence Island polynya from satellite imagery, upward looking sonar, and salinity/temperature moorings. J. Geophys. Res. 108(C5), 3149, doi:10.1029/2001JC001213.

Fowler, C. 2003: Polar Pathfinder daily $25 \mathrm{~km}$ EASE-Grid sea ice motion vectors. Boulder, CO: National Snow and Ice Data Center. Digital media.

Furevik, T. 2001: Annual and interannual variability of Atlantic Water temperature in the Norwegian and Barents seas: 1980-1996. Deep-Sea Res. I 48, 383-404.

Gerdes, R., Karcher, M. J., Kauker, F. \& Schauer, U. 2003: Causes and development of repeated Arctic Ocean warming events. Geophys. Res. Lett. 30, 1980, doi:10.1029/2003 GL018080. 
Golubev, V. A. \& Zuyev, A. N. 1999: Barents and Kara Seas Oceanographic Database (BarKode). IACPO Informal Report 5. Tromsø, Norway: International ACSYS/CliC Project Office.

Haas, C. \& Eicken, H. 2001: Interannual variability of summer sea ice thickness in the Siberian and central Arctic under different atmospheric circulation regimes. J. Geophys. Res. 106(C3), 4449-4462, doi:10.1029/1999 JC000088.

Harms, S., Fahrbach, E. \& Strass, V. H. 2001: Sea ice transports in the Weddell Sea. J. Geophys. Res. 106(C5), 90579073, doi:10.1029/1999JC000027.

Krahmann, G. \& Visbeck, M. 2003: Variability of the Northern Annular Mode's signature in winter sea ice concentration. Polar Res. 22, 51-57.

Kvambekk, A. S. \& Vinje, T. 1992: Ice draft recordings from upward looking sonars (ULSS) in the Fram Strait and the Barents Sea in 1987/88 and 1990/91. Nor. Polarinst. Rapp.ser. 79.

Kvingedal, B. \& Sorteberg, A. unpubl. ms. Atmospheric forcing on the Barents Sea winter ice extent.

Laxon, S., Peacock, N. \& Smith, D. 2003: High interannual variability of sea ice thickness in the Arctic region. Nature 425, 947-950.

Loeng, H. 1991: Features of the physical oceanographic conditions of the Barents Sea. Polar Res. 10, 5-18.

Maslanik, J. A., Serreze, M. C. \& Barry, R. G. 1996: Recent decreases in Arctic summer ice cover and linkages to atmospheric circulation anomalies. Geophys. Res. Lett. 23, 1677-1680, doi:10.1029/96GL01426.

Maslowski, W., Marble, D., Walczowski, W., Schauer, U., Clement, J. L., \& Semtner, A. J. 2004: On climatological mass, heat, and salt transports through the Barents Sea and Fram Strait from a pan-Arctic coupled ice-ocean model simulation. J. Geophys. Res. 109(C3), C03032, doi:10.1029/ 2001JC0010139.

Melling, H. 1997a: Scientific interpretation of sea-ice draft measurements by moored sonar. Appendix 5.10 in P. Lemke \& R. Colony (eds.): Joint report of the fourth session of the ACSYS Sea Ice/Ccean Modeling (SIOM) Panel and the ACSYS Workshop on Sea Ice Thickness Measurements and Data Analysis, Monterey, CA, USA, 7-11 April 1997. WMO Technical Document 991. Available at http:// acsys.npolar.no.

Melling, H. 1997b: Statistical processing of ice-draft obser- vations from moored sonar. Appendix 5.12 in P. Lemke \& R. Colony (eds.): Joint report of the fourth session of the ACSYS Sea Ice/Ocean Modeling (SIOM) Panel and the ACSYS Workshop on Sea Ice Thickness Measurements and Data Analysis, Monterey, CA, USA, 7-11 April 1997. WMO Tech. Doc. 991. Available at http://acsys.npolar.no.

Midttun, L. 1985: Formation of dense bottom water in the Barents Sea. Deep Sea Res. Part A 32, 1233-1241.

NCEP 2003: NCEP/NCAR reanalysis. Boulder, CO: Climate Diagnostics Center, National Oceanographic and Atmospheric Administration. Digital media.

Pfirman, S. L., Bauch, D. \& Gammelsrød, T. 1994: The northern Barents Sea: water mass distribution and modification. In O. M. Johannessen et al. (eds.): The polar oceans and their role in shaping the global environment. Geophys. Monogr. 85, 77-94.

Podgórski, K. Rychlik, I. \& Machado, U. E. B. 2000: Exact distributions for apparent waves in irregular seas. Ocean Eng. 27, 979-1016, doi:10.1016/S0029-8018(99)00030-X.

Rigor, I. G., Colony, R. L. \& Martin, S. 2000: Variations in surface air temperature observations in the Arctic, 197997. J. Clim. 13, 896-914.

Schauer, U., Muench, R. D., Rudels, B. \& Timokhov, L. 1997: Impact of Arctic shelf waters on the Nansen Basin intermediate layers. J. Geophys. Res. 102(C2), 3371-3382.

Simonsen, K. \& Haugan, P. M. 1996: Heat budgets of the Arctic Mediterranean and sea surface heat flux parameterizations for the Nordic seas. J. Geophys. Res. 101(C3), 6553-6576.

Steele, M., Morley, R. \& Ermold, W. 2001: PHC: a global ocean hydrography with a high quality Arctic Ocean. $J$. Clim. 14, 2079-2087.

Strass, V. H. 1998: Measuring sea ice draft and coverage with moored upward looking sonars. Deep Sea Res. Part I 45, 795-818.

Thompson, D. W. J. \& Wallace, J. M. 2000: Annular modes in the extratropical circulation. Part I: month-to-month variability. J. Clim. 13, 1000-1016, doi:10.1175/1520-0442 (2000)013<1000:AMITEC $>2.0 . C O ; 2$.

Vinje, T. 1985: Drift, composition, morphology and distribution of the sea ice fields in the Barents Sea. Nor. Polarinst. Skr. 179 C.

Wadhams, P. 2000: Ice in the ocean. London: Taylor \& Francis. 
